Magdalena Grassmann, Agnieszka Zemke-Górecka, Bogusław Kędra

\title{
Szpitalnictwo cywilne w województwie białostockim w II Rzeczypospolitej
}

Keywords: hospitals, Bialystok Voievodship, Second Republic

\begin{abstract}
Summary
After Poland regained its independence in 1918, Polish people started rebuilding civil hospital network. Bad health conditions of the society and spreading epidemics forced people to undertake the immediate actions. In Bialystok province in the twenties of the twentieth century there were 47 hospitals and among them 18 were epidemic. In following years there appeared the tendency of reducing the amount of hospital institutions. This situation was influenced by the Great Depression in the thirties of the twentieth century. Very often smaller hospitals were merged into one large institution which had several departments with specialized medical staff. The causes of such actions were medical reasons. In the interwar years, in the area of Bialystok province there were also two specialized institutions established. They used innovative ways of treating. It was the Hospital for Mentally and Nervously III in Choroszcz and the Public Institute for Nervously Exhausted in Świack.
\end{abstract}

\section{Wprowadzenie}

Opieka nad zdrowiem jednostki ludzkiej od wieków absorbowała człowieka, począwszy od społeczności plemiennych po cywilizowane społeczeństwo. Zorganizowane formy szpitalnictwa istniały już w czasach starożytnych, w greckich, rzymskich i bizantyjskich kręgach kulturowych. Powstanie sieci szpitali na ziemiach polskich sięga przełomu XI i XII w. ${ }^{1}$ Placówki rozwijały się pod auspicja-

1 A. Zeniuk, Rozwój sieci szpitalnej na ziemiach etnicznie polskich do końca XVIII wieku, „Szpitalnictwo Polskie" 1976, nr 20, s. 254. 
mi Kościoła, w ścisłym powiązaniu z siecią istniejących klasztorów. Z czasem dołączyły do tego fundacje królewskie, mieszczańskie, szlacheckie i magnackie. Ówczesne szpitale miały charakter przytułków, w których znajdowali schronienie zarówno żebracy, starcy, bezdomni, pątnicy, jak i chorzy. Na ziemiach późniejszego województwa białostockiego ${ }^{2}$ pierwsze szpitale powstały $\mathrm{w}$ XV-XVI w. m.in. w Augustowie, Bielsku, Brańsku, Grodnie, Łomży. Aż do końca XVII w. rozwojowi placówek szpitalnych towarzyszyło hasło - Biedny rzeczą świętą, które odzwierciedlało ich charakter. Powolne przeobrażanie się idei szpitala zaczęło się już w XVIII w. Pod wpływem prądów oświeceniowych wprowadzono wiele nowatorskich rozwiązań w funkcjonowaniu i organizacji oraz podstawach prawnych szpitali. Dawne hasło zastąpiło nowe - Chory rzecza świętą. Jednoznaczna funkcja lecznicza szpitala wytworzyła się dopiero w XIX w. Do wybuchu I wojny światowej odnotowywano stały rozwój szpitalnictwa, zwiększanie się kadr medycznych, wprowadzanie nowych rozwiązań prawnych w organizacji placówek. Wojna w znacznym stopniu zniweczyła dotychczasowe osiągnięcia.

\section{Podstawy prawne funkcjonowania sektora zdrowotnego w okresie międzywojennym}

W związku z tym, iż Polska znajdowała się pod zaborami, do roku 1918 nie było jednolitego systemu zdrowotnego pod względem organizacyjnym i prawnym. Z chwilą odzyskania niepodległości pojawiły się dwie koncepcje organizacji opieki zdrowotnej. Pierwszą z nich opracował docent T. Janiszewski, który podkreślał konieczność jednolitego, państwowego systemu zarządzania sprawami zdrowia ${ }^{3}$. Uważał, że powołane w 1918 r. Ministerstwo Zdrowia Publicznego powinno zapewnić administracji rządowej niezbędną samodzielność organizacyjną i finansową w sprawach zdrowia. Druga koncepcja, opracowana przez doktora J. Polaka, zakładała alternatywnie zdecentralizowaną administrację służby zdrowia, której kierownictwo miał sprawować jeden z departamentów Ministerstwa Spraw Wewnętrznych i innych resortów ${ }^{4}$ albo samorządowy nadzór wykonywany przez Ministerstwo Samorządów. Argumentem przemawiającym za wskazywanym modelem była rola przypisywana samorządom, które będąc bliżej społeczeństwa lepiej oceniają jego potrzeby, a tym samym skuteczniej samorząd może sprostać zadaniom sektora zdrowotnego. Zarówno T. Janiszewski, jak J. Polak uwzględniali zasadę przewagi sektora publicznego w lecznictwie. Zwyciężyła pierwsza koncepcja, która ukształtowała państwową, publiczną służbę zdrowia.

2 Według podziału terytorialnego z $1933 \mathrm{r}$.

3 J. Fijałek, J. Machalski, Publiczna opieka zdrowotna u początków Polski Niepodległej, Archiwum Historii Medycyny 1978, XLI, 4, s. 399.

${ }^{4}$ Ibidem. 
Ministerstwo Zdrowia Publicznego sprawowało zwierzchni nadzór nad sprawami zdrowotnymi oraz higieną społeczną. Podlegało mu również samorządowe lecznictwo miejskie oraz samorządowe lecznictwo ubezpieczeniowe. Minister zdrowia publicznego ${ }^{5}$ realizował swoje zadania również przez wojewódzkie wydziały zdrowia publicznego oraz stanowiska urzędowych lekarzy w powiatach i starostwach. W okresie międzywojennym powołano również organy opiniodawcze, wśród nich Rady Zdrowia na szczeblu naczelnym, wojewódzkim i powiatowym. Nadzór sprawowany był nad podmiotami udzielającymi świadczeń zdrowotnych oraz nad towarzystwami medycznymi i fundacjami. Obejmował on także opiekę sanitarno-lekarską nad dzieckiem i matką, chorymi psychicznie, inwalidami i kalekami. Ministerstwo sprawowało nadzór nad środkami spożywczymi i przedmiotami użytku oraz higieną komunalną i przemysłową. W 1927 r. powstał Państwowy Zakład Higieny.

W 1919 r. wydano również zasadniczą ustawę sanitarną ${ }^{6}$ która określała obowiązki samorządów miejskich i wiejskich w zakresie zwalczania chorób zakaźnych oraz innych chorób występujących nagminnie. Wydano także akty prawne $^{7}$, które wprowadzały powszechne, obowiązkowe, bezpłatne szczepienia ochronne. Zadania państwa i samorządów terytorialnych w zakresie zdrowia publicznego zostały określone szczegółowo i precyzyjnie. Administracja państwowa wykonywała funkcje legislacyjne i kontrolne w stosunku do samorządowej służby zdrowia ${ }^{8}$. Samorządy terytorialne były bezpośrednio odpowiedzialne za organizację instytucji ochrony zdrowia $w$ celu zapewnienia odpowiedniej pieczy nad zdrowiem ludności zamieszkałej na ich terenie. Zadania te wykonywano pod nadzorem i opieką władz państwowych. Samorząd zobowiązany był do współdziałania z administracją rządową w zakresie zwalczania chorób zakaźnych i wenerycznych oraz sprawowania opieki nad chorymi psychicznie. Samorząd ponosił wydatki na ochronę zdrowia publicznego, poza kosztami zwalczania chorób zakaźnych i wenerycznych. Gminy mogły ubiegać się o dofinansowanie $\mathrm{z}$ budżetu centralnego $\mathrm{w}$ razie ewentualnych niedoborów. Administracja rządowa była zobowiązana pełnić nadzór epidemiologiczny nad działaniami samorządów, jak też zakładać i utrzymywać szpitale, przychodnie, domy izolacyjne, domy pomocy społecznej i utrzymywać etatowych lekarzy sanitarnych, położne gminne, pielęgniarki i inny niezbędny personel.

System zdrowotny, jeżeli chodzi o jego finansowanie, miał charakter budżetowo-ubezpieczeniowo-samorządowy. Lecznictwo ubezpieczeniowe opierało

${ }^{5}$ Ministerstwo uległo likwidacji w 1924 r. , a jego zadania przejął Departament Zdrowia w Ministerstwie Opieki Społecznej.

6 Zasadnicza ustawa sanitarna z 19 lipca 1919 r., Dz. Pr.P.P., poz. 371.

7 Tytułem przykładu można wskazać Dekret z dnia 7 lutego 1919 roku w przedmiocie przymusowego szczepienia ochronnego przeciwko ospie: Dz.Pr.P.P. Nr 14, poz.180, a następnie ustawa z 19 lipca 1919 r, o przymusowym szczepieniu ochronnym przeciwko ospie, Dz.Pr.P.P. Nr 63, poz. 372.

8 D. Karkowska, Prawa pacjenta, Warszawa 2004, s. 137. 
się początkowo na dekrecie z 11 stycznia 1919 r. o obowiązkowym ubezpieczeniu na wypadek choroby ${ }^{9}$, który został zastąpiony ustawą z 19 maja 1920 r. $^{10}$ Ustawa określiła zasady pomocy lekarskiej dla ludności pracującej. Obowiązkiem ubezpieczenia zostali objęci na równych prawach kobiety i mężczyźni zatrudnieni na podstawie stosunku służbowego lub roboczego. Ustawa nie miała charakteru powszechnego. Nie obejmowała ona rolników, pracowników rolnych i robotników, zwalniała z obowiązku ubezpieczenia pracowników umysłowych o wyższych zarobkach. Członkami kas chorych mogli być zarówno obywatele polscy, jak i cudzoziemcy. Kasy chorych w celu zapewnienia świadczeń leczniczych mogły tworzyć własną sieć zakładów leczniczych o charakterze podstawowym i stacjonarnym, jak też prowadzić ambulatoria, apteki, sanatoria, domy dla ozdrowieńców, zakłady leczenia fizykalnego, instytuty diagnostyczne. Ubezpieczeni mogli ponadto korzystać ze szpitali publicznych i prywatnej służby zdrowia, o ile jednostki te miały zawartą umowę z kasą chorych. Osoby ubezpieczone korzystały z bezpłatnej pomocy lekarskiej, nie było wówczas określonego koszyka świadczeń zdrowotnych, jednak bezpłatna pomoc lekarska miała na celu przywrócenie zdrowia i zdolności zarobkowania lub jedynie utrzymanie zdolności zarobkowania. Leczenie szpitalne w odróżnieniu od pomocy lekarskiej nie było bezpłatne. Kasa chorych pokrywała jedynie połowę kosztów w najniższej klasie świadczenia i standardzie, drugą część musiał pokryć sam ubezpieczony. Jedynie w przypadkach, gdy kasa chorych wystąpiła $z$ umieszczeniem chorego w wyższej klasie leczenia, musiała pokryć pełny koszt pobytu. Jeśli natomiast ubezpieczony zgłosił się do szpitala ze skierowaniem wskazującym na najniższą taryfę opłat i sam zażądał podwyższonego standardu usług, szpital był zobowiązany uwzględniać to żądanie, jednak chory w chwili przyjęcia musiał zapłacić różnicę między połową najniższej taryfy opłat i taksą klasy wyższej ${ }^{11}$.

Ustawa z 19 maja 1920 r. o obowiązkowym ubezpieczeniu na wypadek choroby $^{12}$ obowiązywała na obszarze II Rzeczypospolitej z wyjątkiem Górnego Śląska (gdzie uchwalono odrębną ustawę ubezpieczeniową z dnia 19 lipca 1920 r.). Działalnością kasy kierowała rada. Spośród jej członków wybierano zarząd oraz komisję rewizyjną i rozjemczą. Kasy chorych tworzyły związki okręgowe, które przeprowadzały kontrolę działalności poszczególnych kas, zawierały umowy z lekarzami, zakładami leczniczymi, organizacjami lekarskimi, zakładały i utrzymywały apteki oraz szpitale, jak również koordynowały działania w zakresie profilaktyki. Nadzór nad realizacją zadań wykonywanych przez kasy chorych sprawował Urząd Ubezpieczeń. W wyniku reform powstało lecznictwo społecz-

\footnotetext{
9 Dz. Pr. P.P. Nr 9, poz. 122.

${ }^{10}$ Dz.U. z 1920 r. Nr 44, poz. 272.

${ }^{11}$ Okólnik w sprawie przyjmowania do szpitala, Ministerstwo Pracy i Opieki Społecznej, Departament Ubezpieczeń Społecznych z 1921 r., Nr 19.

12 Dz.U. R.P. z 1920 r. Nr 44, poz. 276.
} 
no-samorządowe. Kasy chorych dzięki jasno określonemu terytorium z własnym aparatem leczniczym z czasem stawały się agendą administracyjno-finansową opieki zdrowotnej, która wypierała drogi sektor prywatny, jak też tańszy, lecz o niskim standardzie, sektor miejski ${ }^{13}$. Jak podkreśla J. Fijałek, samorządność w lecznictwie spełniała trzy podstawowe idee: państwo dopuszczało pracowników do organów władzy w sektorze zdrowotnym, pozwalało na możliwość wybierania tych organów i podejmowania decyzji w granicach określonych przez prawo $^{14}$. Budziło to jednak niezadowolenie oponentów lecznictwa samorządowego, a kryzys ekonomiczny stał się ich sprzymierzeńcem. W 1933 r. zniesiono kasy chorych i powołano w ich miejsce ubezpieczalnie społeczne na mocy ustawy z 28 marca 1933 r. ${ }^{15}$, zwanej scaleniową. Zmiana systemu spowodowała centralizację i podporządkowanie ubezpieczalni społecznych Ministerstwu Opieki Społecznej. Ubezpieczalnie społeczne zobowiązane były do ustalania obowiązku ubezpieczenia, wyznaczania wysokości składek ubezpieczeniowych i ich pobierania, kontroli pracodawców w zakresie uiszczania składek, przyznawania i udzielania świadczeń w zakresie ubezpieczenia na wypadek choroby i macierzyństwa. Ustawa scaleniowa nie objęła wszystkich obywateli. Wprowadzono zmiany w lecznictwie podstawowym przez zastosowanie systemu lekarza domowego, który miał zapewnić całość świadczeń leczniczych, a w przypadku wymagającym dodatkowego leczenia uprawniony był do skierowania do lekarza specjalisty lub szpitala. Ustawa odstępowała od bezpłatności pomocy leczniczej i wprowadziła dopłaty za poszczególne świadczenia. Ubezpieczony miał prawo do bezpłatnego leczenia szpitalnego jedynie w najniższej klasie szpitalnej. Struktura opieki zdrowotnej opierała się na lecznictwie ubezpieczeniowym i pozaubezpieczeniowym. Wśród aktów prawnych okresu międzywojennego należy zauważyć ustawę o publicznej służbie zdrowia z 1939 r. ${ }^{16}$, która dała podstawy do tworzenia administracji służby zdrowia, ale ze względu na wybuch II wojny światowej wykorzystana została po jej zakończeniu.

Status prawny publicznych i prywatnych zakładów opieki zdrowotnej, nazywanych wówczas zakładami leczniczymi, oraz kompetencje organów nimi zarządzających, określało rozporządzenie z mocą ustawy wydane przez Prezydenta Rzeczypospolitej z 22 marca $1928 \mathrm{r} \cdot{ }^{17} \mathrm{~W}$ publicznych zakładach działały tzw. rady szpitalne. Nadzór nad zakładami został powierzony ministrowi zdrowia publicznego. Zakłady lecznicze podzielono na dwie grupy: zakłady lecznicze dla osób potrzebujących stałego pomieszczenia w celu leczenia i pielęgnowania

${ }^{13}$ J. Fijałek, Kasa Chorych - pierwowzór społecznego, samorządowego lecznictwa pracowniczego $w$ Polsce, Archiwum Historii Medycyny 1984, 47, 1.

${ }^{14}$ Ibidem, s. 103.

${ }^{15}$ Ustawa z dnia 28 marca 1933 roku o ubezpieczeniu społecznym, Dz. U. z 1933 r., Nr 51, poz. 396.

${ }^{16}$ Ustawa z dnia 15 czerwca o publicznej służbie zdrowia, Dz. U. z 1939 r., Nr 54, poz. 342.

${ }^{17}$ Dz.U. R.P. z 1928 r., Nr 38, poz. 382. 
względnie obserwacji i porady lekarskiej (które można było również podzielić na szpitale i lecznice) oraz zakłady lecznicze dla osób przychodzących (przychodnie). W świetle rozporządzenia szpitale były prowadzone bez zamiaru osiągania zysku, natomiast lecznice zakładały osiąganie zysku, prowadzone były przez indywidualnych lekarzy bądź przez spółdzielnie pracy lekarzy, lekarzy dentystów lub techników dentystycznych. Przedmiotowe rozporządzenie przewidywało zarówno status publiczności, jak i prywatności zakładu (tzw. szpitale bez prawa publiczności). W przypadku szpitala bez prawa publiczności chorzy mieli prawo do takiej opieki zdrowotnej, która w minimalnym zakresie odpowiadała świadczeniom oferowanym w szpitalach publicznych. W przypadku lecznic ustawodawca pozostawił dowolność w zakresie standardu, ale wydano stosowne rozporządzenia, które określały minimalny standard techniczny i sanitarny budynków oraz urządzeń leczniczych warunkujących możliwość funkcjonowania zakładu leczniczego.

Lecznictwo obejmowało cztery sektory: publiczny, państwowy, społeczny i prywatny. Sektor publiczny stanowiło przede wszystkim lecznictwo miejskie. Gminy w ramach wykonywania zadania publicznego, jakim jest ochrona zdrowia publicznego, zakładały i utrzymywały szpitale oraz urządzenia sanitarne. W miastach powyżej 25000 ludności zakładano zakłady lecznicze i szpitale dla chorych zakaźnie, domy izolacyjne i zakłady dezynfekcyjne. Do obowiązków gmin należy zaliczyć również opiekę nad psychicznie chorymi oraz zapewnienie chorym, którzy nie byli objęci ubezpieczeniem społecznym i nie posiadali wystarczających środków finansowych, opieki lekarskiej. Do sektora państwowego należało lecznictwo wojskowe, które obejmowało również policję państwową oraz urzędników państwowych i rodziny funkcjonariuszy. Były to grupy najbardziej uprzywilejowane. Funkcjonariusze policji państwowej oraz urzędnicy państwowi wraz z rodzinami mogli leczyć się w szpitalach i poradniach innych sektorów na zasadzie pełnej refundacji kosztów. W sektorze społecznym placówki szpitalne, ambulatoria prowadzone były przez towarzystwa dobroczynne, gminy wyznaniowe, instytucje społeczne. Sektor prywatny rozwinął działalność przede wszystkim w zakresie poradnictwa medycznego, lekarzy wolno praktykujących oraz lecznic. W sektorze pozaubezpieczeniowym leczenie było odpłatne, chyba że pacjent na mocy szczególnych przepisów zwolniony był od ponoszenia opłat. Jeśli lekarz musiał udzielić pomocy nieubezpieczonemu, mógł żądać honorarium wedle cennika ustalonego w rozporządzeniu o zakładach leczniczych, a jeżeli nie uzyskiwał go, to obowiązek taki spoczywał na związku komunalnym ${ }^{18}$. Koszty leczenia szpitalnego obliczano na podstawie opłaty dziennej, która uzależniona była od klasy, do której chory został przyjęty. Chory, który nie posiadał środków finansowych na leczenie szpitalne, zobowiązany był uzyskać z urzędu komu-

${ }^{18}$ D. Karkowska, Prawa..., s. 141. 
nalnego świadectwo ubóstwa i na jego podstawie był przyjmowany do szpitala. $\mathrm{W}$ razie nagłego zachorowania wskazywany dokument mógł być dostarczony później. Świadectwo ubóstwa nie uprawniało chorego do pokrycia kosztów przewozu do i ze szpitala oraz kosztów pomocniczych przyrządów leczniczych.

Zakłady lecznicze prowadzone przez podmioty administracji publicznej w okresie dwudziestolecia międzywojennego możemy zaliczyć do kategorii zakładów publicznych. T. Bigo ${ }^{19}$ wskazywał, iż jest to „kompleks środków osobowych i materialnych należących do państwa, względnie innego podmiotu administracji publicznej, a wydzielony pod względem organizacyjnym w jedną całość i służący celom administracji publicznej”. W. Klonowiecki ${ }^{20}$ sformułował zbieżną definicję, przyjmując, że jest to zespół osób, rzeczy i praw zorganizowany przez administrację publiczną i trwale $\mathrm{z}$ nią związany, przeznaczony do indywidualnego użytkowania przez inne osoby uprawnione lub zobowiązane. W okresie międzywojennym istniała koncepcja podziału zakładów administracyjnych na samoistne i niesamoistne. Podział ten uzależniony był od przymiotu posiadania osobowości prawnej. W. Klonowiecki uważał, że „...zakłady publiczne samoistne są podmiotami administracji publicznej, będąc osobami prawnymi sprawują funkcje administracji publicznej samodzielnie, nie podlegają władzy hierarchicznej organów administracji rządowej, są zatem jedną z form decentralizacji”21.

\section{Etapy rozwoju szpitalnictwa}

W 1918 r. odrodzone państwo polskie stanęło przed trudnym zadaniem odbudowy powojennych zniszczeń. Skutki wojny, a więc przemarsze wojsk, masowy ruch uchodźczy, nadmierne skupienie ludności, szczególnie w miastach, nędza, dezorganizacja służby zdrowia we wczesnym okresie powojennym powodowały rozwój chorób epidemicznych ${ }^{22}$. Przez Polskę, a szczególnie województwo białostockie przetoczyły się epidemie ospy, duru plamistego, powrotnego i brzusznego, czerwonki, błonicy oraz płonicy. Duży problem stanowiły również choroby społeczne: gruźlica, jaglica, alkoholizm, choroby weneryczne, psychiczne. Sytuację dodatkowo pogarszała niska świadomość zdrowotna mieszkańców, zwłaszcza wsi. Dbanie o zdrowie w omawianym okresie nie było zachowaniem rozpowszechnionym. Wynikało ze specyfiki środowiska i kultury zdrowotnej ludności. Zależało od poziomu wiedzy społeczeństwa, a przede wszystkim od jego możliwości socjalno-ekonomicznych. Jednym z priorytetów stało się więc

${ }^{19}$ T. Bigo, Związki publicznoprawne w świetle ustawodawstwa polskiego, Warszawa 1928, s. 178.

${ }^{20}$ W. Klonowiecki, Zakład publiczny w prawie polskim, Lublin 1933, s. 121.

${ }^{21}$ Ibidem, s. 221.

${ }_{22}$ U. Sztuka-Polińska, Sytuacja epidemiologiczna niektórych ostrych chorób zakaźnych $w$ Polsce w okresie międzywojennym XX wieku, „Przegląd Epidemiologiczny” 2002, nr 56, s. 137-138. 
odbudowanie sieci szpitali, zapewniających prawidłowe leczenie i opiekę, wyizolowanie chorych zakaźnie, zmniejszenie śmiertelności.

Rozwój szpitalnictwa na terenie województwa białostockiego w okresie międzywojennym kształtował się etapami. Bardzo trudna sytuacja epidemiologiczna na początku lat dwudziestych XX w. wymusiła powstanie gęstej sieci szpitali epidemicznych. Na podstawie zachowanych sprawozdań o stanie zdrowotnym ludności w Rzeczypospolitej Polskiej wiadomo, że w 1923 r. istniało na terenie województwa białostockiego 47 szpitali dysponujących 2293 łóżkami dla chorych. Najwięcej, bo 18 szpitali, podlegało Naczelnemu Nadzwyczajnemu Komisarzowi do walki z epidemiami. Szpitale o profilu epidemicznym urządzono również w istniejących wcześniej placówkach komunalnych bądź sejmikowych. W województwie białostockim zorganizowano jedną z czterech w kraju ekspozytur podległych Urzędowi Naczelnego Nadzwyczajnego Komisarza do walki $\mathrm{z}$ epidemiami ${ }^{23}$. W Białymstoku istniała duża stacja etapowa ze szpitalem, do której kierowano chorych ze stacji kwarantannowych, przeprowadzano badania, kąpiele, dezynsekcje ${ }^{24}$. Dwa lata później stan szpitalnictwa przedstawiał się zdecydowanie odmiennie. Na terenie omawianego województwa liczba szpitali zmniejszyła się do 38, z 1603 łóżkami ${ }^{25}$. Stało się to za sprawą przede wszystkim zniesienia szpitali epidemicznych wobec względnej stabilizacji zachorowalności na choroby zakaźne. Te placówki epidemiczne, których istnienie uznano za konieczne, przekazano samorządom terytorialnym. Dotyczyło to szpitali w Białymstoku, Bielsku, Brańsku, Sokółce, Grajewie i Orli. W połowie lat dwudziestych XX w. na terenie województwa największy procent szpitali stanowiły placówki publiczne, tj. należące do samorządów, związków komunalnych oraz miejskie. Obok nich istniały szpitale sektora społecznego, prowadzone przez Polski Czerwony Krzyż oraz żydowską gminę wyznaniową ${ }^{26}$. W 1933 r. powstał także jedyny w II Rzeczpospolitej Państwowy Zakład dla Nerwowo Wyczerpanych w Świacku ${ }^{27}$. Należy przy tym podkreślić, że na terenie województwa brak było szpitali z sektora ubezpieczeniowego należących do kas chorych, a później

${ }^{23}$ Sprawozdanie o stanie zdrowotnym Rzeczypospolitej Polskiej oraz o działalności władz i instytucji zdrowia publicznego w roku 1923, Warszawa 1925, s. 42

${ }^{24}$ Dwadzieścia lat publicznej stużby zdrowia w Polsce Odrodzonej 1918-1938, Warszawa 1939, s. 47.

${ }_{25}$ Tabela. Stan szpitalnictwa w Polsce w 1925/1926 r. [w:] Sprawozdanie o stanie zdrowotnym Rzeczypospolitej Polskiej oraz o działalności władz i instytucji zdrowia publicznego w roku 1925, Warszawa 1927.

${ }^{26}$ Szpitale PCK funkcjonowały w Białymstoku oraz w Brańsku, placówki prowadzone przez żydowską gminę wyznaniową istniały w Białymstoku, Łomży, Suwałkach, Grodnie i Wołkowysku.

${ }^{27}$ W 1935 r. zorganizowano podobny Państwowy Zakład Leczniczy dla Nerwowo Wyczerpanych Kobiet w Gościejewie koło Poznania. Zob. Szpitale psychiatryczne w Polsce, Polskie Towarzystwo Szpitalnictwa, t. III, 1937, s. 24-25. 


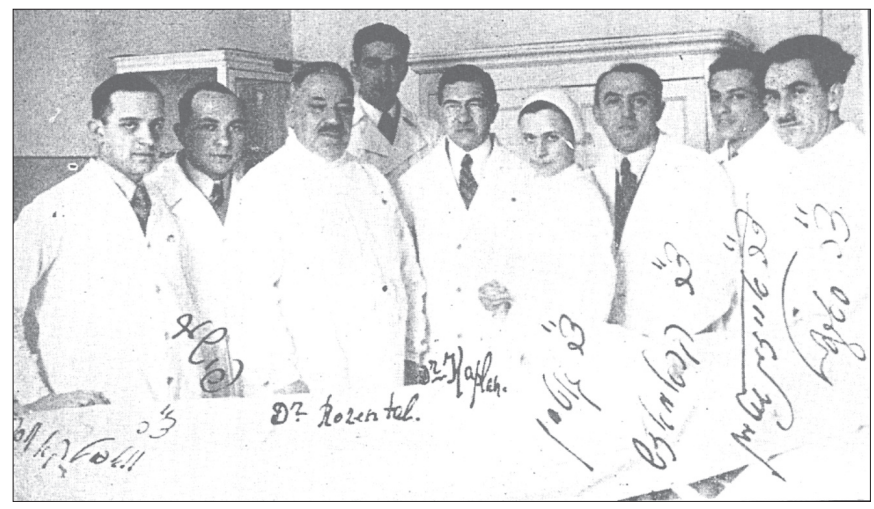

Fot.1. Personel szpitala żydowskiego w Białymstoku

Źródło: D. Sohn, Bialystok. Photo album of a renowned city and its Jews the world over, New York 1995, s. 89.

do Ubezpieczalni Społecznej ${ }^{28}$. W takich wypadkach osoby ubezpieczone mogły korzystać ze szpitali samorządowych.

Kryzys gospodarczy, jaki dotknął państwo polskie na początku lat 30 . $\mathrm{XX}$ w. miał swoje odzwierciedlenie również w dziedzinie szpitalnictwa. Finanse samorządowe wielu związków komunalnych nie wystarczały na pokrycie bieżących potrzeb. W związku z tym wiele placówek szpitalnych zostało zlikwidowanych. W 1932 r. liczba szpitali w województwie białostockim spadła z 29 do $23^{29}$. Znacznie zmniejszyła się liczba łóżek. Szpitale, które funkcjonowały miały problemy z zakupem podstawowych środków wyposażenia, bielizny, czy narzędzi medycznych. Utrzymywanie w dalszym ciągu dużej liczby niewielkich szpitali okazało się nieopłacalne.

W kraju podjęto inicjatywę łączenia mniejszych szpitali ${ }^{30}$. Dążono do stworzenia sieci dużych, dobrze wyposażonych placówek z odpowiednio przygotowanym i opłaconym personelem medycznym. Zlikwidowano szpitale, których prowadzenie było niewspółmiernie drogie z rezultatami ich działalności. Kasowano placówki, których przeciętne obłożenie nie przekraczało 6-10 łóżek ${ }^{31}$. Postulaty komasacji wysuwano szczególnie pod adresem szpitali miejskich: w Białymstoku planowano włączyć do szpitala św. Rocha pozostałe miejskie placówki. Podobna sytuacja zaistniała w Grodnie; uważano za konieczne połą-

${ }^{28}$ Szpitali kas chorych w omawianym okresie nie posiadały województwa: białostockie, lubelskie, wileńskie, nowogródzkie, poleskie, wołyńskie, stanisławowskie, tarnopolskie i pomorskie. J. Sadowska, Kasy Chorych w Polsce w latach 1920-1933, Łódź 2002, s. 105.

${ }^{29}$ Archiwum Państwowe w Białymstoku (dalej: AP Białystok), Sprawozdanie wojewody białostockiego za rok 1932/1933, Urząd Wojewódzki Białostocki, sygn. 310, s. 27-28.

${ }^{30}$ W. Przywieczerski, M. Heyman, Szpitale w Polsce, „Zdrowie” 1932, nr 9-10, s. 356.

${ }^{31}$ Państwowe Archiwum Obwodu Grodzieńskiego w Grodnie (dalej: PAOG), Sprawozdanie wojewody białostockiego za czas od 01.04.1931-01.04.1932, Białystok 1933, sygn. 2127, s. 19. 
Tabela 1. Szpitale województwa białostockiego w 1932 r.

\begin{tabular}{|c|l|l|}
\hline Lp. & \multicolumn{1}{|c|}{ Miejscowość } & \multicolumn{1}{c|}{ Nazwa szpitala } \\
\hline 1 & Augustów & powiatowy \\
\hline 2 & Knyszyn & rejonowy \\
\hline 3 & Bielsk Podlaski & PCK \\
\hline 4 & Brańsk & miejski \\
\hline 5 & Grodno & żydowski \\
\hline 6 & Grodno & św. Ducha \\
\hline 7 & Łomża & żydowski \\
\hline 8 & Łomża & powiatowy \\
\hline 9 & Ostrołęka & powiatowy \\
\hline 10 & Ostrów Mazowiecka & powiatowy \\
\hline 11 & Sokółka & miejski \\
\hline 12 & Suwałki & żydowski \\
\hline 13 & Suwałki & powiatowy \\
\hline 14 & Szczuczyn & powiatowy \\
\hline 15 & Wołkowysk & żydowski \\
\hline 16 & Wołkowysk & powiatowy \\
\hline 17 & Wysokie Mazowieckie & miejski św. Łazarza \\
\hline 18 & Białystok & żydowski \\
\hline 19 & Białystok & miejski św. Rocha \\
\hline 20 & Białystok & miejski w Zwierzyńcu \\
\hline 21 & Białystok & PCK \\
\hline 22 & Białystok & międzykomunalny \\
\hline 23 & Choroszcz & \\
\hline & & Dion \\
\hline
\end{tabular}

Źródło: opracowanie własne na podstawie AP Białystok, Sprawozdanie wojewody białostockiego za rok 1932, sygn. 310, k. 21, 21v.

czenie 2 szpitali: związku powiatowego oraz miasta. W Suwałkach postulowano połączenie szpitala św. Piotra i Pawła ze szpitalem żydowskim, zwłaszcza że oba szpitale mieściły się w tym samym budynku ${ }^{32}$.

Od 1936 r. sytuacja szpitali zaczęła się stabilizować. Związane to było z ożywieniem gospodarczym kraju. Chociaż liczba placówek szpitalnych nie wzrastała, odnotowywano ciągły wzrost liczby łóżek. W rezultacie w 1937 r. na terenie województwa białostockiego istniało 21 szpitali, w których do dyspozycji cho-

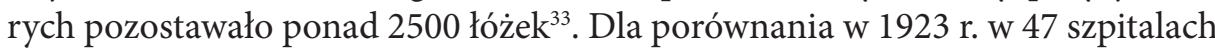
były tylko 2293 łóżka.

32 PAOG, Sprawozdanie wojewody białostockiego za czas od 01.04.1931-01.04.1932, Białystok 1933, sygn. 2127, s. 111.

${ }^{33}$ PAOG, Sprawozdanie wojewody białostockiego za 1937 rok, sygn. 2130, s. 26. 


\section{Szpitalnictwo ogólne i specjalistyczne}

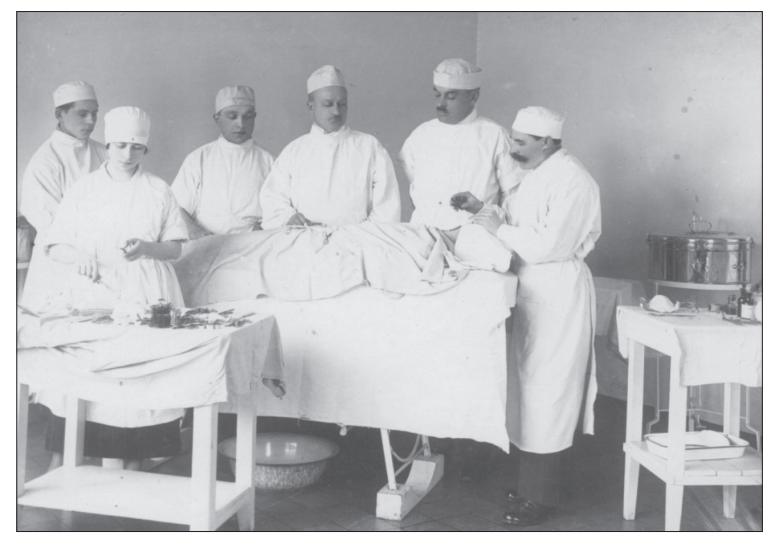

Fot. 2. Operacja przeprowadzana w szpitalu miejskim św. Rocha w Białymstoku

Źródło: zbiory Biblioteki Głównej UMB, f. 63.

Szpitale okresu międzywojennego były placówkami nastawionymi przede wszystkim na leczenie urazów chirurgicznych, chorób wewnętrznych oraz przypadków położniczo-ginekologicznych (tabela 1). Pod względem liczby oddziałów najkorzystniej przedstawiały się szpitale miejskie. Najczęściej usytuowane były w obszernych budynkach mogących zmieścić od 60 do 150 chorych, zatrudniały wykwalifikowaną kadrę medyczną oraz posiadały lepsze warunki finansowe. W Białymstoku szpital św. Rocha w 1938 r. dysponował czterema oddziałami: chirurgicznym, zakaźnym, położniczym i skórno-wenerycznym. Suwalski szpital św. Piotra i Pawła liczył pięć oddziałów: wewnętrzny, chirurgiczny, zakaźny, weneryczny i położniczy. Z czasem doszedł szósty - gruźliczy ${ }^{34}$. Szpital w Grodnie dysponował łóżkami na oddziałach: wewnętrznym, chirurgicznym, ginekologicznym, zakaźnym i wenerycznym. Szpital łomżyński posiadał oddział wewnętrzny, chirurgiczny i położniczy ${ }^{35}$. Szpital w Wołkowysku liczył cztery oddziały: chirurgiczny, wewnętrzny, położniczy i zakaźny ${ }^{36}$.

Placówki prowadzone przez Polski Czerwony Krzyż dysponowały mniejszą niż ww. szpitale liczbą łóżek, miały też ograniczoną liczbę oddziałów. Białostocki szpital PCK mieszczący się przy ul. Warszawskiej 29 prowadził jedynie oddział wewnętrzny i chirurgiczny ${ }^{37}$. Jako jedyny w województwie wyodrębnił łóżka przeznaczone dla dzieci ${ }^{38}$.

\footnotetext{
${ }^{34}$ Suwałki. Miasto nad Czarną Hańcza, praca zbior. pod red. J. Kopciała, Suwałki 2005, s. 368.

${ }_{35}$ Rocznik Lekarski Rzeczypospolitej Polskiej na 1936 rok, oprac. S. Konopka, Warszawa 1936, s. 610 .

${ }^{36}$ Ibidem, s. 1544.

${ }^{37}$ Polski Czerwony Krzyż. Sprawozdanie Okręgu Białostockiego za 1932 r., Białystok 1933, s. 10.

${ }^{38}$ Sale przeznaczone dla dzieci i młodzieży znajdowały się na drugim piętrze budynku. Zob. Szpital Czerwonego Krzyża, „Dziennik Białostocki” 1921, nr 115, s. 1.
} 


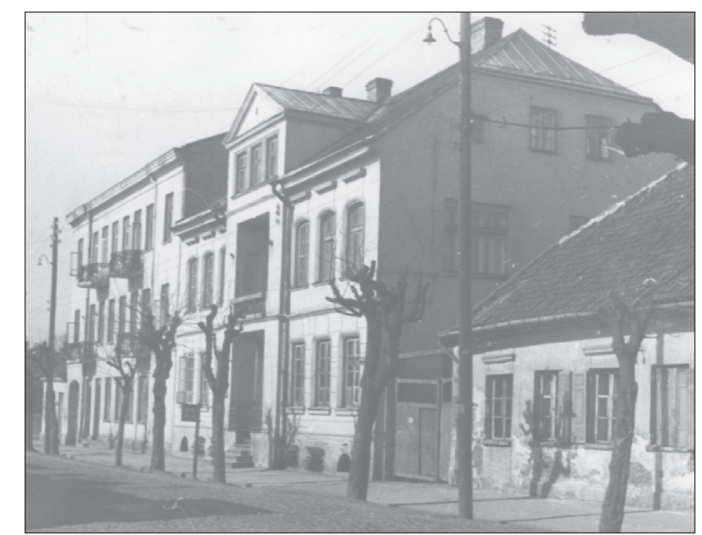

Fot. 3. Szpital PCK w Białymstoku

Źródło: Zbiory Biblioteki Głównej UMB, f. 363.

Odmiennie przedstawiała się sytuacja poza największymi ośrodkami miejskimi województwa. Mniejsze szpitale powiatowe, których średnia liczba łóżek oscylowała wokół 30, miały charakter wybitnie internistyczny. Przyjmowano w nich oczywiście przypadki chirurgiczne i ginekologiczno-położnicze, a w nagłych potrzebach również i zakaźne. Jednak kubatura zajmowanych budynków, niewielkie nakłady finansowe oraz nieliczna kadra medyczna nie pozwalały na szeroko zakrojoną działalność tych placówek. Cięższe przypadki chorobowe odsyłano do szpitali miejskich.

Tabela 2. Liczba łóżek w szpitalach województwa białostockiego z podziałem na oddziały.

Zestawienie na podstawie sprawozdań za czas od 1 IV 1934-31 III $1935^{39}$

\begin{tabular}{|c|c|c|c|c|c|c|c|c|c|c|c|}
\hline Szpital & 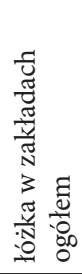 & 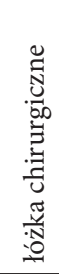 & 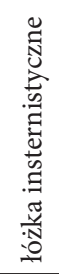 & 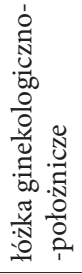 & 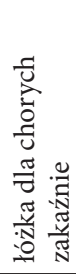 & 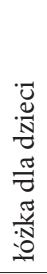 & 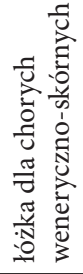 & 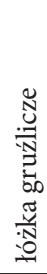 &  & 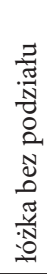 & 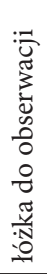 \\
\hline Komunalny & 1630 & 225 & 201 & 121 & 177 & - & 68 & 12 & 800 & 24 & 2 \\
\hline Społeczny & 313 & 100 & 145 & 19 & 32 & 5 & - & - & - & 12 & - \\
\hline Razem & 1943 & 325 & 346 & 140 & 209 & 5 & 68 & 12 & 800 & 36 & 2 \\
\hline
\end{tabular}

Źródło: J. Bujalski, Rzut oka na stan i działalność zakładów leczniczych państwowych, komunalnych, społecznych i prywatnych na podstawie sprawozdań za rok 1934-1935, Warszawa 1936, tabl. II.

${ }^{39}$ Zestawienie nie obejmuje lecznic prywatnych dysponujących 80 łóżkami. 
Obok wymienionych szpitali ogólnych, w miastach tworzono placówki specjalistyczne. Ich powstawanie było związane z wysoką wówczas zachorowalnością na choroby zakaźne, weneryczne oraz wysokim wskaźnikiem śmiertelności niemowląt i matek. Należy jednak podkreślić, że w dwudziestoleciu międzywojennym wśród mieszkańców, szczególnie wsi, panowała obawa przed hospitalizacją zakorzeniona jeszcze w poprzednich wiekach. Opór w otoczeniu chorego, uniemożliwiający izolację, powodował dalsze szerzenie się choroby. Zła sytuacja finansowa ludności często uniemożliwiała pobyt w szpitalu, a w związku z tym nie zgłaszano przypadku choroby. Ludność, szczególnie wiejska, nadal chętnie korzystała z pomocy miejscowych znachorów, „babek” ${ }^{40}$. Dlatego też tak duża była rola szpitala. Dążono, by ówczesny szpital był w równej mierze instytucją leczniczą, jak i zakładem wychowawczym. Chory, lecząc się, miał jednocześnie uczyć się jak postępować, aby zapobiec dalszemu rozwojowi choroby ${ }^{41}$.

Po zlikwidowaniu szpitali epidemicznych okazało się, że jest potrzeba funkcjonowania placówek zajmujących się chorobami zakaźnymi. Odrębne szpitale zakaźne działały więc w Białymstoku, Łomży, Sejnach. Do walki z chorobami wenerycznymi zorganizowano w województwie trzy placówki. W Białymstoku, pod kierownictwem dr Jana Walewskiego, działał skórno-weneryczny szpital św. Łazarza posiadający kilka odrębnych miejsc do leczenia chorych prostytutek ${ }^{42}$. W Łomży przy Urzędzie Sanitarno-Obyczajowym funkcjonował szpital św. Wojciecha. Placówka zajmująca się leczeniem chorób wenerycznych istniała na początku lat dwudziestych także w Grodnie.

Złe warunki sanitarne panujące $\mathrm{w}$ dwudziestoleciu międzywojennym w miastach i na wsiach, niedożywienie oraz korzystanie z usług ludowych „medyków” przyczyniały się $\mathrm{w}$ wysokim stopniu do śmiertelności niemowląt i matek. Chociaż wszystkie szpitale w województwie posiadały łóżka ginekologiczno-położnicze, istniała tylko jedna wykwalifikowana placówka. Był to początkowo Miejski Przytułek Położniczy działający w Białymstoku przy ul. Kraszewskiego. Trzy lata później został on przekształcony w Miejski Szpital i przeniesiony do pokoszarowego budynku w Zwierzyńcu ${ }^{43}$. Prowadzony przez specjalistę - dr Witolda Bajenkiewicza, szpital stał na wysokim poziomie pod względem organizacji i skuteczności leczenia. Pomagało to przełamywać dawne nawyki społeczeństwa. Coraz więcej kobiet decydowało się rodzić w szpitalu.

${ }^{40}$ M. Posłuszna, Stan zdrowia społeczeństwa polskiego II Rzeczypospolitej w perspektywie początku XXI wieku, „Pielęgniarstwo Polskie” 2005, nr 2, s. 515.

${ }^{41}$ B. Krippendorf, Kilka słów o społecznych zadaniach szpitali powszechnych $w$ dobie obecnej, „Zdrowie Publiczne" 1938, nr 2, s. 139.

${ }^{42}$ Archiwum Akt Nowych, Stan sanitarny osiedli - województwo białostockie 1927-1929, Ministerstwo Opieki Społecznej, Departament Służby Zdrowia, sygn. 788, k. 88.

${ }^{43} \mathrm{Na}$ początku lat trzydziestych Szpital Miejski w Zwierzyńcu został włączony do szpitala św. Rocha. Zob. J. Walewski, Szpitale i zakłady lecznicze na terenie miasta Białegostoku w okresie od 1919 do 1944, „Roczniki Akademii Medycznej w Białymstoku” 1964, nr 10, s. 3-8. 
W okresie międzywojennym zmianie uległo podejście do chorób psychicznych, nerwic i uzależnień. Wychodząc naprzeciw problemowi braku dostatecznej liczby łóżek psychiatrycznych w kraju, powstało kilka nowych, dużych ośrodków leczących tego typu przypadłości. W województwie białostockim zorganizowano jeden z największych szpitali na wschód od Wisły ${ }^{44}$. W 1930 r. na terenie dawnej fabryki włókienniczej w Choroszczy otwarto Szpital dla Psychicznie i Nerwowo Chorych. Dzięki profesjonalnemu i pełnemu pasji podejściu organizatorów placówki do chorych, szpital był traktowany jako ośrodek higieny psychiatrycznej. Dyrektor szpitala dr Stanisław Deresz wielokrotnie podkreślał, że celem zakładu nie było odgraniczanie chorych od społeczeństwa ani też odstraszanie ich od szpitala. W placówce umieszczano tylko takie przypadki chorych, których stan tego wymagał. Szpital, w zamyśle doktora, był rodzajem filtra, a nie składnicą chorych wyrzuconych ze społeczeństwa ${ }^{45}$. Chorych leczono najnowszymi wówczas metodami: wstrząsami insulinowymi, cardiazolowymi oraz gorączką i szeroko rozwiniętą terapią pracy ${ }^{46}$. Przebywający w szpitalu pacjenci najczęściej cierpieli na schizofrenię, niedorozwój umysłowy, padaczkę, alkoholizm i narkomanię, zaburzenia psychiczne po urazach oraz pochodzenia miażdżycowego.

Z obliczeń statystycznych wynikało, że jeden na 1000 mieszkańców potrzebował opieki w zakładzie specjalistycznym. Pomimo 1000 miejsc w szpitalu w Choroszczy, liczba łóżek była wciąż za mała. W 1933 r. w celu objęcia opieką większej liczby chorych zastosowano tzw. opiekę przyzakładową. Powodem jej zorganizowania - jak twierdził dyrektor Stanisław Deresz - było to, że spokojni chronicy zajmowali miejsce w szpitalu, a tysiące ostrych chorych nie mogło korzystać z leczenia zakładowego ${ }^{47}$. Chorzy umieszczeni w opiece przyzakładowej przebywali w promieniu 7-8 km od szpitala, w dwudziestu czterech okolicznych wsiach. Byli jednak pod stałym nadzorem lekarzy oraz pielęgniarek. Do każdego gospodarstwa przyjmowano maksymalnie 3-4 chorych z zaznaczeniem, aby na każdą dorosłą osobę przypadał jeden chory. Chory wychodził do opieki całkowicie wyekwipowany: dostawał ubranie, dwie zmiany bielizny, metalowe łóżko, pościel. Gospodarze obowiązani byli opiekować się chorym, karmić go, w miarę możliwości zatrudniać do odpowiednich zajęć. Za opiekę i utrzymanie szpital płacił za każdego chorego jeden złoty dziennie ${ }^{48}$. Korzyści płynące z za-

${ }^{44}$ Przed zorganizowaniem szpitala psychiatrycznego w Choroszczy jedynie przy szpitalu żydowskim w Białymstoku przeznaczono kilka łóżek dla chorych z zaburzeniami psychicznymi. Głównym celem była bardziej izolacja niż faktyczne leczenie. Zob. R. Zabłotniak, Białostocka służba zdrowia do 1944 roku, Białystok 1964, s. 72 (praca doktorska).

${ }^{45}$ Biblioteka Uniwersytetu Medycznego w Białymstoku, Księga protokołów zebrań Polskiego Zrzeszenia Lekarzy Województwa Białostockiego, sygn. R. 55.

${ }^{46}$ J. Bartoszewski, Państwowy Szpital dla Nerwowo i Psychicznie Chorych w Choroszczy, s. 3 (maszynopis w zbiorach Muzeum Historycznego w Białymstoku).

${ }^{47}$ Ibidem, s. 3.

${ }^{48}$ Sprawozdanie z działalności Białostockiego Wojewódzkiego Szpitala dla Psychicznie i Nerwowo Chorych za rok 1933, Choroszcz 1934, s. 2-3. 
stosowania opieki pozazakładowej były obopólne. Chory przystosowywał się do normalnego życia, często zżywał się ze swoim gospodarzem i był traktowany jak członek rodziny. Wśród miejscowej ludności zmieniało się podejście do osób cierpiących na dolegliwości psychiczne. Ważny był również czynnik ekonomiczny. Wynagrodzenia za opiekę stanowiły duży zastrzyk gotówki w skromnym budżecie rolników. Przez zastosowanie takiej formy opieki, szpital był odciążony i mógł przyjmować więcej cięższych przypadków chorobowych; koszt utrzymania chorego u opiekunów był znacznie niższy niż na oddziałach.

Chorobami społecznymi o znacznym spektrum występowania w omawianym okresie był alkoholizm i wszelkiego rodzaju uzależnienia. Jedynym ośrodkiem leczącym te schorzenia był otwarty w 1933 r. Państwowy Zakład dla Nerwowo Wyczerpanych w Świacku. Do celów leczniczych zaadaptowano XVIII-wieczny zabytkowy pałac Wołłowiczów, który wraz z otaczającym go parkiem i ogrodami zajmował powierzchnię ponad 100 hektarów. Wskazaniami leczniczymi oprócz alkoholizmu były: morfinizm, kokainizm, nadużywanie środków nasennych, nerwice i psychonerwice, stany wyczerpania nerwowego oraz rekonwalescencje popsychotyczne ${ }^{49}$. Leczono metodami psychoterapeutycznymi, uwzględniając właściwości psychiczne każdego kuracjusza. Zakład wyposażony był w nowoczesne urządzenia do wodolecznictwa, elektroterapii oraz światłolecznictwa. Innym ważnym czynnikiem leczniczym stosowanym w Świacku była praca i zajęcia sportowe. Kuracjusze uczestniczyli w warsztatach rzemieślniczych, pracach ogrodniczych i w gospodarstwie rolnym.

\section{Wnioski}

Sytuacja epidemiologiczna na początku lat dwudziestych XX w. wymusiła powstanie sieci szpitali epidemicznych w województwie białostockim. W $1923 \mathrm{r}$. było ich 18 na 47 istniejących szpitali. Szybkie zorganizowanie tego typu placówek przyczyniło się do stłumienia epidemii chorób zakaźnych zagrażających nie tylko Polsce, ale i zachodniej Europie. W latach 1919-1924 istniało wiele szpitali wojskowych. Lecznictwo w województwie białostockim opierało się na placówkach publicznych prowadzonych przez jednostki samorządu terytorialnego i związki komunalne. Obok nich istniały szpitale sektora społecznego prowadzone przez Polski Czerwony Krzyż oraz żydowską gminę wyznaniową. W odróżnieniu od innych województw nie powstały na terenie województwa białostockiego szpitale z zakresu sektora ubezpieczeniowego, które bądź to należały do kas chorych, a od 1933 r. do ubezpieczalni. Od początku lat trzydziestych sytuacja na polu szpitalnictwa uległa zmianie. Komasowano niewielkie

\footnotetext{
${ }^{49}$ Świack. Państwowy Zakład Leczniczy dla nerwowo wyczerpanych, b.r. i m.w., s. 2-6.
} 


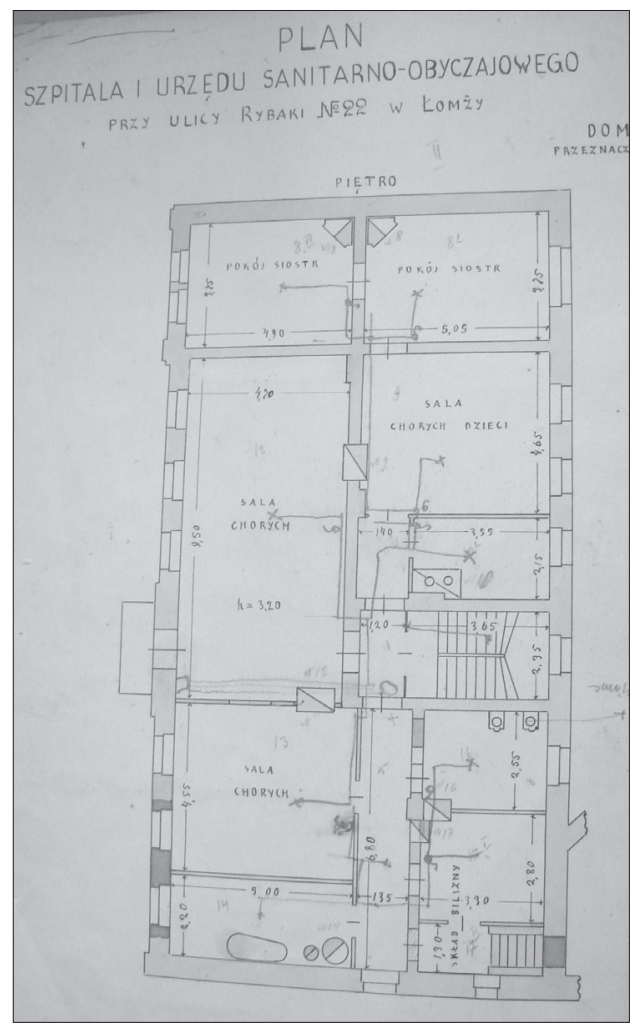

Fot. 4. Plan szpitala św. Wojciecha w Łomży (oddział męski w domu frontowym)

Źródło: AP Łomża, Akta miasta

Łomży, sygn. 42.

placówki na rzecz organizowania dużych szpitali ulokowanych w nowoczesnych budynkach. Na gruzach powojennej pożogi powstała sieć wyspecjalizowanych placówek, dobrze wyposażonych, posiadających po kilka oddziałów, kierowanych przez odpowiednią kadrę lekarzy społeczników. Przemiany, jakie dokonały się w omawianym okresie w myśli medycznej, olbrzymie zapotrzebowanie oraz sprzyjające podejście władz spowodowały rozwój szpitalnictwa specjalistycznego. Dotyczyło to głównie leczenia chorób psychicznych, nerwic oraz wszelkich uzależnień. W 1933 r. powstał także jedyny w II Rzeczypospolitej Państwowy Zakład dla Nerwowo Wyczerpanych w Świacku, a następnie w Choroszczy. Województwo białostockie jako jedno z niewielu w skali kraju zyskało dwie tego typu placówki. Od 1936 r. sytuacja szpitali zaczęła się stabilizować. Związane to było z ożywieniem gospodarczym kraju. W rezultacie w 1937 r. na terenie województwa białostockiego istniało 21 szpitali, w których do dyspozycji chorych pozostawało więcej łóżek niż wówczas, gdy funkcjonowało 47 małych szpitali.

Okres II Rzeczypospolitej w sektorze szpitalnictwa cywilnego na terenie województwa białostockiego był pod znakiem dynamicznego rozwoju placówek, nowatorskich rozwiązań prawnych oraz postępu w traktowaniu poszczególnych jednostek chorobowych. 